\title{
Soil water availability for drip-irrigated common bean crop ${ }^{1}$
}

\author{
Edson Fagne dos Santos 2 , Silvanio Rodrigues dos Santos ${ }^{3}$, \\ Abner José de Carvalho ${ }^{3}$, Ignácio Aspiazu ${ }^{3}$, Polyanna Mara de Oliveira ${ }^{4}$
}

\section{ABSTRACT}

Minimum limits of soil water storage should be established for the irrigation management of crops, in order to satisfactorily provide water to plants. This study aimed to define the soil water availability factor ( $f$ factor) that provides the maximum agronomic yield and maximum water-use efficiency for drip-irrigated common bean cultivars. The experiment was carried out in a randomized block design, with four replications. The treatments were arranged in split plots, with the plots consisting of $f$ factors $(0.20,0.35,0.50,0.65$ and 0.80$)$ and subplots consisting of common bean cultivars (BRS Pérola and BRS Estilo). The use of $f$ factors between 0.30 and 0.35 is recommended for common bean crops to obtain the maximum agronomic yield and maximum water-use efficiency. The BRS Estilo cultivar presents a water-use efficiency $16 \%$ higher than the BRS Pérola.

KEYWORDS: Phaseolus vulgaris L., water availability factor, irrigation management.

\section{INTRODUCTION}

Common bean (Phaseolus vulgaris L.) is one of the most important foods for human consumption in the world (Castro-Guerrero et al. 2016). However, its production in several regions has been affected by water deficit, especially in semiarid regions (Ambachew et al. 2015, Andrade et al. 2016, Darkwa et al. 2016, Lanna et al. 2016).

Several studies have shown significant losses in common bean yield due to water deficit (Asfaw \& Blair 2014, Ambachew et al. 2015, Dipp et al. 2017). However, the excess of soil moisture is also a factor

\section{RESUMO}

Disponibilidade de água no solo para feijoeiro-comum irrigado por gotejamento

Limites mínimos de armazenamento de água no solo devem ser estabelecidos para o manejo de irrigação das culturas, a fim de fornecer água às plantas de maneira satisfatória. Objetivou-se definir o fator de disponibilidade de água no solo (fator $f$ ) que proporcione o máximo rendimento agronômico e a máxima eficiência no uso de água de feijoeiro-comum irrigado por gotejamento. O experimento foi conduzido em delineamento de blocos ao acaso, com quatro repetições. Os tratamentos foram arranjados em esquema de parcelas subdivididas, sendo as parcelas compostas pelos fatores $f(0,20 ; 0,35 ; 0,50 ; 0,65$; e 0,80$)$ e as subparcelas pelas cultivares BRS Pérola e BRS Estilo. Recomenda-se a utilização de fator $f$ entre 0,30 e 0,35 para a obtenção de máximo rendimento agronômico e máxima eficiência no uso de água pelo feijoeiro-comum. BRS Estilo apresenta eficiência no uso de água $16 \%$ maior que BRS Pérola.

PALAVRAS-CHAVE: Phaseolus vulgaris L., fator de disponibilidade de água, manejo de irrigação.

that may affect the crop yield (Carvalho et al. 2013), due to changes in the plant physiology (Osakabe et al. 2014, Lanna et al. 2016). Thus, the maintenance of a satisfactory soil water level is necessary for a good crop performance.

The common bean sensitivity to water stress and the low water availability and poor rainfall distribution in semiarid regions make the use of irrigation indispensable to meet the water demand of crops. This low availability of water resources increases the need for saving water for a greater use efficiency, as well as its preservation and improvement to ensure the environmental

1. Received: Feb. 21, 2019. Accepted: Aug. 21, 2019. Published: Nov. 14, 2019. DOI: 10.1590/1983-40632020v5057367.

2. Universidade Federal de Viçosa, Departamento de Fitotecnia, Viçosa, MG, Brasil.

E-mail/ORCID: fagner-edson07@hotmail.com/0000-0002-6462-3253.

3. Universidade Estadual de Montes Claros, Departamento de Ciências Agrárias, Janaúba, MG, Brasil.

E-mail/ORCID: silvanio.santos@unimontes.br/0000-0003-0245-9184, abner.carvalho@unimontes.br/0000-0002-6644-5307, ignacio.aspiazu@unimontes.br/0000-0002-0042-3324.

4. Empresa de Pesquisa Agropecuária de Minas Gerais, Unidade Regional Norte de Minas, Nova Porteirinha, MG, Brasil. E-mail/ORCID: polyanna.mara@epamig.br/0000-0002-9892-373X. 
sustainability of food production in these regions (Medrano et al. 2015).

The proper crop irrigation management can be done by establishing minimum soil water storage limits to satisfactorily provide water to plants (Vieira et al. 2015a), which are between $250 \mathrm{~mm}$ and $300 \mathrm{~mm}$ for the common bean crop (Brasil 2018). These limits can be established by using the soil water availability factor $(f)$ (Mantovani et al. 2009), which should be 0.5 for an evapotranspiration demand of $5 \mathrm{~mm} \mathrm{day}^{-1}$ for the common bean crop, i.e., plants can consume up to $50 \%$ of all available water in the soil (Allen et al. 2006). However, the $f$ factor needs to be determined for each condition, since it may vary depending on the characteristics of the plant, environment and soil, considering that, within each ideal $f$ range for the best performance of each crop, the lowest value should be considered for sandy soils, and the highest one for clayey soils (Marouelli et al. 2011).

Therefore, the adoption of cultivars more adapted to low soil water conditions, associated with the use of efficient irrigation managements, can contribute to increase the crop yield (Nepomucemo et al. 2001, Ambachew et al. 2015) and to decrease the water consumption. This response depends on the genotype and age of the plants and intensity and duration of the stress conditions to which they are subjected (Olsovska et al. 2016).

BRS Pérola is a common bean cultivar released in 1994 that is tolerant to water and thermal deficits and is still preferred by producers, mainly because of its rusticity (Hoffman Júnior et al. 2007, Vale et al. 2012), despite new cultivars have been released with similar or superior characteristics.

The BRS Estilo cultivar was released in 2009. It presents an erect plant growth habit and resistance to lodging; thus, it is adapted to mechanical harvesting. Moreover, this cultivar has a high yield potential and is resistant to the major common bean diseases. Melo et al. (2011) found a higher yield for this cultivar, when compared to BRS Pérola; however, BRS Estilo is still little known, what makes interesting the study of this cultivar.

Considering the importance of the common bean crop in Brazil and in the world, information on the minimum soil moisture that increases the plant yield and water-use efficiency, especially in arid and semiarid regions, can assist in reducing the water consumption of crops and food production costs, as well as generate a greater environmental sustainability.
Thus, this study aimed to define the soil water availability factor ( $f$ factor) that provides the maximum agronomic yield and water-use efficiency of two drip-irrigated common bean cultivars.

\section{MATERIAL AND METHODS}

The experiment was carried out at the experimental area of the Universidade Estadual de Montes Claros, in Janaúba, Minas Gerais state,

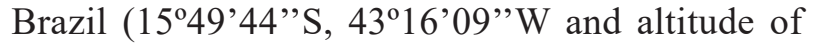
$544 \mathrm{~m}$ ), from August to October 2017. The soil of the area is classified as a Typic Quartzipsamment (Neossolo Flúvico Psamítico) (Embrapa 2013) of sandy texture, which presented a total water storage capacity of $38 \mathrm{~mm}$ in the $0-0.2 \mathrm{~m}$ layer, due to its high proportion of medium and fine sands in the sand fraction.

The climate of the region is classified as Aw, tropical with a dry season, according to the Köppen classification (Alvares et al.2013). Data of maximum, average and minimum temperatures were collected from a meteorological station at the experimental area (Figure 1).

Soil samples were collected from the $0.0-0.2 \mathrm{~m}$ and 0.2-0.4 $\mathrm{m}$ layers before the implementation of the experiment to characterize the physical-hydrological properties of soil density and the water retention curve at tensions of $6 \mathrm{kPa}, 10 \mathrm{kPa}, 33 \mathrm{kPa}, 100 \mathrm{kPa}$, $500 \mathrm{kPa}$ and 1,500 kPa (Table 1).

Sensors (Watermark ${ }^{\circledR}$ ) were installed in each treatment, to measure the soil moisture in the middle of the soil layers (0.0-0.2 $\mathrm{m}$ and $0.2-0.4 \mathrm{~m})$, with daily readings throughout the experiment.

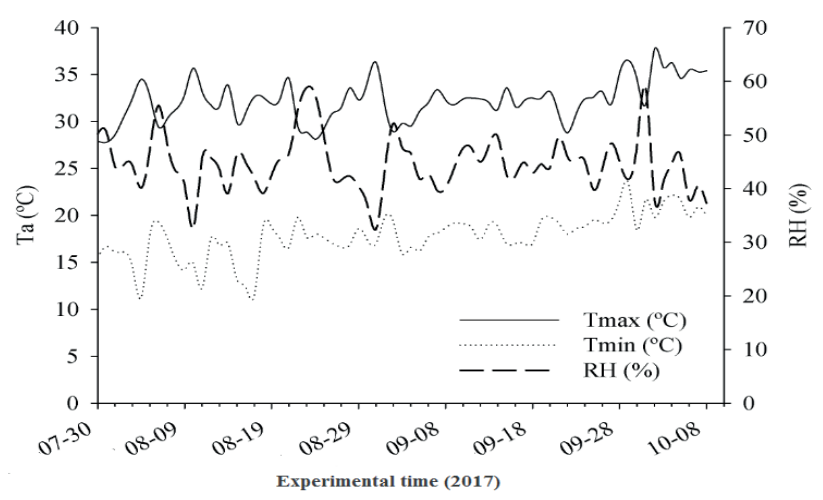

Figure 1. Air temperature $\left(\mathrm{Ta},{ }^{\circ} \mathrm{C}\right)$ and relative humidity $(\mathrm{RH}, \%)$ during the experiment period (Janaúba, Minas Gerais state, Brazil, 2017). 
Table1. Soil water retention equations and their coefficient of determination $\left(\mathrm{R}^{2}\right)$; soil moisture at field capacity $\left(\mathrm{FC}, \mathrm{m}^{3} \mathrm{~m}^{-3}\right)$ and at permanent wilting point (PWP, $\left.\mathrm{m}^{3} \mathrm{~m}^{-3}\right)$; and apparent soil density $\left(\rho_{\mathrm{s}}, \mathrm{g} \mathrm{cm}^{3}\right)$, from two soil depths in the experimental area.

\begin{tabular}{cccccc}
\hline Soil depth $(\mathrm{m})$ & Equation $^{1}$ & $\mathrm{R}^{2}$ & $\mathrm{FC}$ & $\mathrm{PWP}$ & $\rho_{\mathrm{s}}$ \\
\hline $0.0-0.2$ & $\theta=0.0299+[(0.410-0.0299)] /\left[1+(0.10 \times \tau)^{1.7475}\right]^{0.4278}$ & 0.99 & 0.2324 & 0.0389 & 1.39 \\
$0.2-0.4$ & $\theta=0.0221+[(0.425-0.0221)] /\left[1+(0.10 \times \tau)^{1.7543}\right]^{0.4300}$ & 0.98 & 0.2357 & 0.0313 & 1.39 \\
\hline
\end{tabular}

${ }^{1} \theta$ : volume-based moisture; $\tau$ : soil water tension $(\mathrm{kPa})$.

The water stresses found in the readings of the soil moisture sensors were used to develop retention curves to determine the irrigations (Table 1). The readings of the sensors installed at $0.1 \mathrm{~m}$ were used to define the irrigation regime (variable watering shift) according to the water availability factors ( $f$ factors) evaluated, which corresponded to pressure head of $28(f=0.20), 38$ $(f=0.35), 54(f=0.50), 85(f=0.65)$ and 166 $(f=0.80) \mathrm{kPa}$. The irrigation regime maintained the soil moisture to a tension corresponding to the field capacity $(20 \mathrm{kPa})$, which was defined by the basin method (Bernardo et al. 2019) up to the effective depth of the root system $(0.3 \mathrm{~m})$, thus determining the irrigation depths to be applied in each treatment (Bernardo et al. 2019).

The experiment was conducted in a randomized block design, with four replications. The treatments were arranged in split plots, with plots consisting of five soil water availability factors ( $f$ factors) $\left(f_{1}=0.20 ; f_{2}=0.35 ; f_{3}=0.50 ; f_{4}=0.65 ; f_{5}=0.80\right)$ and subplots consisting of two common bean cultivars (BRS Pérola and BRS Estilo). Each subplot consisted of two 4-m double plant rows spaced at $0.3 \mathrm{~m} \times 0.7 \mathrm{~m}$, sowed with 12 seeds per meter. The two central rows were considered for evaluation, disregarding $1.5 \mathrm{~m}$ of each end.

All plots were irrigated from the beginning of sowing up to 27 days after sowing (DAS), to maintain the soil moisture close to the field capacity and favor the initial growth and establishment of the crop. Subsequently, they were irrigated whenever the soil moisture reached the value established for each treatment, by replacing the water to the limits of the soil water availability ( $f$ factor) of each treatment. Additionally, the soil moisture of each experimental plot was determined weekly by the standard method (Bernardo et al. 2019), during the application of the treatments.

A drip-irrigation system was used, with spacing of $1 \mathrm{~m}$ between tubes and $0.33 \mathrm{~m}$ between emitters, a wet area of $60 \%$, flow rate of $2 \mathrm{~L} \mathrm{~h}^{-1}$ (average of 5 evaluations), working pressure of $150 \mathrm{kPa}$ and application efficiency of $94 \%$.

The soil was fertilized after planting through fertigation, which was divided into six applications, until the application of the treatments, using $40 \mathrm{~kg} \mathrm{ha}^{-1}$ of $\mathrm{N}(45 \%$ of $\mathrm{N}$ urea, $12 \%$ of N MAP and $13 \%$ of N $\left.\mathrm{KNO}_{3}\right), 70 \mathrm{~kg} \mathrm{ha} \mathrm{p}^{-1}$ of $\mathrm{P}_{2} \mathrm{O}_{5}\left(60 \%\right.$ of $\mathrm{P}_{2} \mathrm{O}_{5}$ purified MAP) and $30 \mathrm{~kg} \mathrm{ha}^{-1}$ of $\mathrm{K}_{2} \mathrm{O}\left(44 \%\right.$ of $\left.\mathrm{K}_{2} \mathrm{O} \mathrm{KNO}_{3}\right)$, according to Vieira et al. (2015b). Micronutrients were applied using FTE BR12 (1.8\% of B, $0.8 \%$ of $\mathrm{Cu}$, $3.0 \%$ of Fe, $2.0 \%$ of $\mathrm{Mn}$ and $0.1 \%$ of Mo), at a rate of $15 \mathrm{~kg} \mathrm{ha}^{-1}$. Liming was not performed.

Foliar fertilization was applied at 35 DAS (R5 stage), using CoMo (Co, Mo and $\mathrm{P}_{2} \mathrm{O}_{5}$ at $10.56 \mathrm{~g} \mathrm{~L}^{-1}$, $105.6 \mathrm{~g} \mathrm{~L}^{-1}$ and $132 \mathrm{~g} \mathrm{~L}^{-1}$, respectively) at a rate of $300 \mathrm{~mL} \mathrm{ha}^{-1}$.

The yield components evaluated after the harvest were: number of pods per plant, number of grains per pod, 100-grain weight and grain yield. The number of pods per plant and number of grains per pod were estimated from the total pods and grains produced in the subplot, and the 100-grain weight was estimated by dividing the total grain weight ( $\mathrm{g}$ ) of the subplot by its respective number of grains and multiplying the result by 100 . Grain yield was estimated by the amount of grains harvested in the evaluation area of the subplots, being expressed as $\mathrm{kg}$ $\mathrm{ha}^{-1}$. The results considered a grain moisture of $13 \%$. The irrigation depths were summed to determine the water-use efficiency $\left(\mathrm{kg} \mathrm{m}^{-3}\right)$, the ratio between the average grain yield $\left(\mathrm{kg} \mathrm{ha}^{-1}\right)$ and the applied irrigation water depths $\left(\mathrm{m}^{3} \mathrm{ha}^{-1}\right)$. After the pod maturation, the number of accumulated degree-days required to the common bean crop complete its cycle was calculated using the method proposed by Villa Nova et al. (1972), and $10^{\circ} \mathrm{C}$ was used as the lower base temperature (Tb), according to Manfron et al. (1993). The degree-days (DD) were calculated for each day by the following equations: $\mathrm{DD}=[(\mathrm{TM}-\mathrm{Tm}) / 2]+$ $(\mathrm{Tm}-\mathrm{Tb})$, if $\mathrm{Tm}>\mathrm{Tb} ; \mathrm{DD}=(\mathrm{TM}-\mathrm{Tb})^{2} / 2(\mathrm{TM}-$ $\mathrm{Tm})$, if $\mathrm{Tm}<\mathrm{Tb}$; and $\mathrm{DD}=0$, if $\mathrm{Tb}>\mathrm{TM}$, where: $\mathrm{TM}$ is the maximum daily temperature $\left({ }^{\circ} \mathrm{C}\right)$, Tm the 
minimum daily temperature $\left({ }^{\circ} \mathrm{C}\right)$ and $\mathrm{Tb}$ the lower basal temperature $\left({ }^{\circ} \mathrm{C}\right)$.

The data were submitted to analysis of variance, prioritizing the decomposition of significant interactions at $5 \%$ of probability $(\mathrm{p}<0.05)$. The quantitative source of variation ( $f$ factor) was subjected to regression analyses, with the model coefficients tested by t-Student $(\mathrm{p}<0.05)$. The choice of the model was also based on the determination coefficient $\left(\mathrm{R}^{2}\right)$ of the models. The means for the qualitative source of variation (cultivar) were compared by the F-test $(p<0.05)$. The analyses were performed using the Sisvar software (Ferreira 2014).

\section{RESULTS AND DISCUSSION}

The common bean cycle was 70 days, without differences between the cultivars. The water applied to the common bean crops reached $137.7 \mathrm{~mm}$ for each treatment up to the application of the treatments (27 DAS) (Table 2). Subsequently, the water depths

Table 2. Water depths before the application of the treatments (WDBT, mm), total water depths (TWD, mm) and number of irrigations (NI) applied on common bean cultivars submitted to soil water availability factors ( $f$ factor).

\begin{tabular}{cccc}
\hline$f$ factor & WDBT & TWD & NI \\
\hline 0.20 & 137.7 & 275.9 & 40 \\
0.35 & 137.7 & 309.9 & 37 \\
0.50 & 137.7 & 294.0 & 33 \\
0.65 & 137.7 & 249.3 & 30 \\
0.80 & 137.7 & 221.7 & 28 \\
\hline
\end{tabular}

ranged from $84.0 \mathrm{~mm}$ for the highest $f$ factor $(0.8)$ to $172.1 \mathrm{~mm}$ for the lowest $(0.35)$ one. The treatment with an $f$ factor of 0.35 received a water depth $105 \%$ higher than that with an $f$ factor of 0.8 , which received the lowest water depth during the common bean cycle. The lower the $f$ factor, the higher was the irrigation frequency (Table 2). According to Vieira et al. (2015a), the minimum number of irrigations is operationally ideal, requiring less labor and electricity consumption for irrigation. However, long intervals between irrigations generate drier soil conditions for the crops, making it difficult for plants to absorb water and leading to water stress.

According to the analysis of variance, the interaction between soil water availability levels $(f$ factor) and cultivars was not significant for any of the evaluated variables (Table 3 ). The $f$ factors had a significant effect on the number of pods per plant, number of grains per pod, grain yield and water-use efficiency. The cultivars had a significant effect on all the evaluated characteristics (Table 3 ).

The variables data fitted a quadratic regression model. The number of pods per plant, number of grains per pod, grain yield and water-use efficiency (Figures 2A, 2B, 2C and 2D) decreased sharply when using $f$ factors of 0.65 and 0.8 , which had the largest intervals between irrigations and lower water depths (Table 2). The maximum number of pods per plant and number of grains per pod were obtained by using the $f$ factors of 0.35 and 0.30 , respectively. Factors lower and higher than these caused a decrease in these variables.

The applied water depths and the decreases in yield components using the lowest $f$ factor

Table 3. Analysis of variance for number of pods per plant (NPP), number of grains per pod (NGP), 100-grain weight (100GW, g), grain yield $\left(\mathrm{GY}, \mathrm{kg} \mathrm{ha}^{-1}\right)$ and water-use efficiency (WUE, $\mathrm{kg} \mathrm{m}^{-3}$ ) for the BRS Pérola and BRS Estilo cultivars grown in the semiarid region of the Minas Gerais state, Brazil, under water availability factors ( $f$ factor).

\begin{tabular}{lcccccc}
\hline \multicolumn{1}{c}{$\begin{array}{c}\text { Source of } \\
\text { variation }\end{array}$} & Degrees & \multicolumn{5}{c}{ Mean square } \\
\cline { 3 - 7 } & of freedom & NPP & NGP & $100 \mathrm{GW}$ & GY & WUE \\
\hline$f$ factor & 4 & $16.96^{* *}$ & $4.52^{* *}$ & $8.28^{\text {ns }}$ & $1,314,016.51^{* *}$ & $0.120^{* *}$ \\
Block & 3 & $4.91^{* *}$ & $0.20^{\text {ns }}$ & $4.58^{\text {ns }}$ & $213,139.58^{* *}$ & $0.029^{* *}$ \\
Error (a) & 12 & 1.22 & 0.29 & 621.86 & $60,177.32$ & 0.008 \\
Cultivar & 1 & $6.48^{*}$ & $3.86^{* *}$ & $78.76^{* *}$ & $157,363.23^{*}$ & $0.022^{*}$ \\
$f$ factor $\times$ cultivar & 4 & $1.23^{\text {ns }}$ & $0.08^{\text {ns }}$ & $4.05^{\text {ns }}$ & $70,975.61^{\text {ns }}$ & $0.009^{\text {ns }}$ \\
Error (b) & 15 & 0.76 & 0.14 & 340.49 & $31,170.10$ & 0.004 \\
\hline CV $_{\text {(a) }}(\%)$ & & 24.64 & 14.91 & 10.77 & 29.91 & 30.440 \\
VV $_{\text {(b) }}(\%)$ & & 19.41 & 10.26 & 7.97 & 21.52 & 21.670 \\
Overall mean & & 4.49 & 3.65 & 23.15 & 820.28 & 0.292 \\
\hline
\end{tabular}

${ }^{1} \mathrm{CV}$ : coefficient of variation for the plot (a) and subplot (b); * and ** significant values by the F-test at $5 \%$ or $1 \%$ of probability, respectively; ${ }^{\text {ns }}$ not significant values by the F-test at $5 \%$ of probability. 

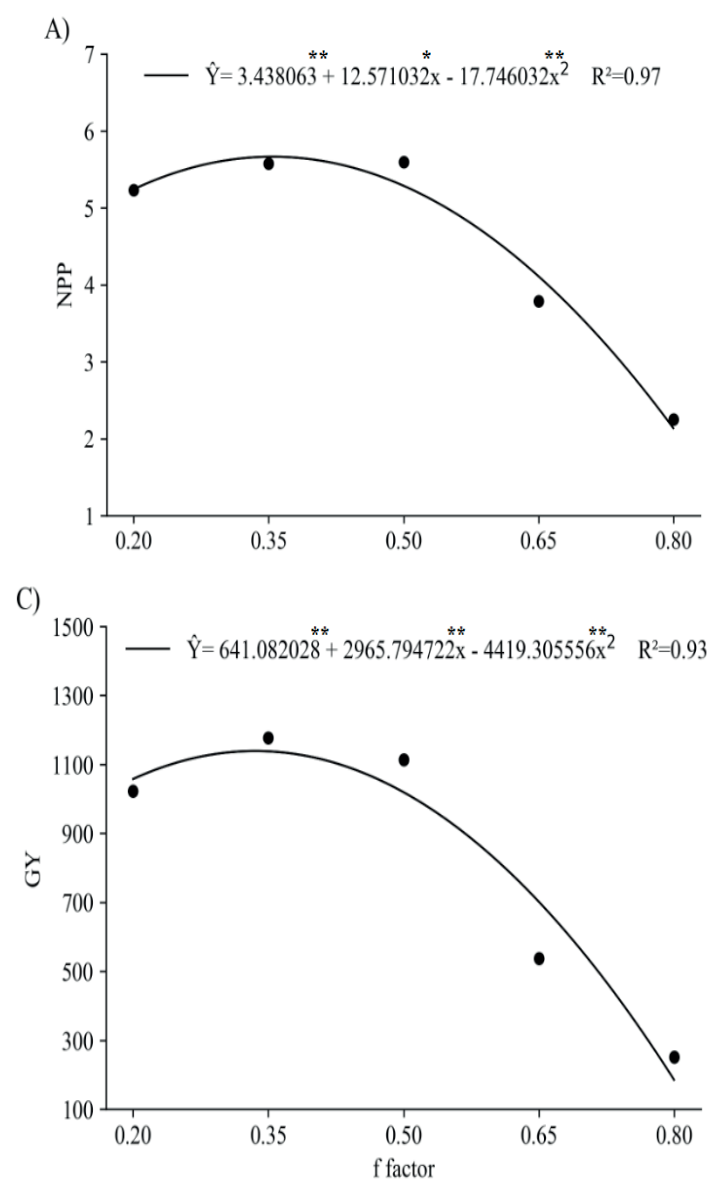
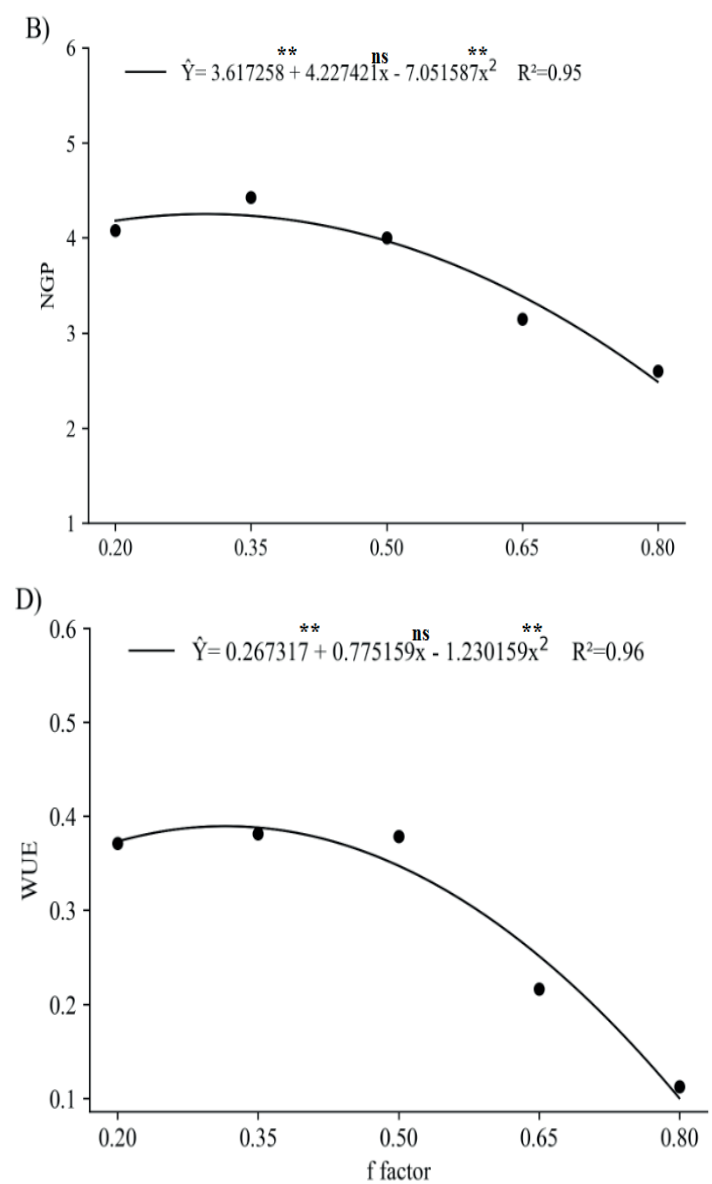

Figure 2. Number of pods per plant (NPP) (A), number of grains per pod (NGP) (B), grain yield (GY, kg ha $\left.{ }^{-1}\right)(\mathrm{C})$ and water-use efficiency (WUE, $\mathrm{kg} \mathrm{m}^{-3}$ ) (D) of common bean cultivars grown under soil water availability factors $(f$ factor).

evaluated in the present study are explained by the soil characteristics. The moisture at the soil water retention capacity decreases as the $f$ factor increases from 0.35 to 0.20 .

The number of pods per plant and number of grains per pod of plants treated with $f$ factors of 0.35 and 0.30 were, respectively, $62.27 \%$ and $41.51 \%$ higher than those of plants treated with the highest $f$ factor evaluated. These variables presented lower percentages when using higher $f$ factors. These decreases are attributed to increases in the water stress conditions caused to plants as the $f$ factor is increased. Water deficit periods cause changes in the photosynthetic rate (Osakebe et al. 2014, Lanna et al. 2016) and stressful metabolic conditions to plants, which lead to energy and sugar depletion and negatively affect their grain quality and yield (Cuellar-Ortiz et al. 2008).

The $f$ factors had no significant $(\mathrm{p}>0.05)$ effect on the 100 -grain weight, probably due to the lower number of pods per plant and number of grains per pod of plants under the highest water deficit conditions. Endres et al. (2010) explain this result by the adaptive aspects of plants, since it is more beneficial to plants to produce fewer seeds under unfavorable conditions, what ensures enough reserves to support the spread of the species. Common bean plants reduce their number of grains per pod and number of pods per plant as a defense mechanism to accumulate reserves and satisfactorily produce pods and grains. Thus, the plants under stress conditions had a similar 100-grain weight to that of plants under no stress, because the low soil water and photosynthetic rate at the highest $f$ factors were enough to promote a satisfactory grain filling.

According to the model presented in Figure 2D, the maximum grain yield $\left(1,138.4 \mathrm{~kg} \mathrm{ha}^{-1}\right)$ is obtained with the $f$ factor of 0.34 , being $83.7 \%$ higher than that obtained with the highest $f$ factor evaluated. This highest grain yield is related to the highest number of 
pods per plant and number of grains per pod found with $f$ factors at close intervals. Grain yield is related to the number of grains per pod, number of pods per plant and 100-grain weight (Lemos et al. 2004), which indicate more productive cultivars under low water availability (Darkwa et al. 2016). The decreases in grain yield found in the present study due to the increases in the $f$ factors are consistent with the reports of Ambachew et al. (2015) and Asfaw \& Blair (2014), who found decreases in grain yield of approximately $80 \%$ for common bean plants subjected to low water availability.

The high temperatures in the field during the crop period (Figure 1), above $30{ }^{\circ} \mathrm{C}$ and reaching $35^{\circ} \mathrm{C}$ in some days, are important factors that may have contributed to the significant decreases in grain yield. Temperature is important to establish the most appropriate times of the year for the good performance of common bean. Ribeiro et al. (2014) also found a low grain yield in several common bean genotypes and attributed the results to the high temperatures occurred in the reproductive period and to a probable decrease in the number of grains per pod.

According to Vieira et al. (2006c), high temperatures trigger the process of abscission of reproductive organs in the common bean crop, and temperatures above $35^{\circ} \mathrm{C}$ practically prevent the pod formation, with a significant effect on the final yield. Moreover, common bean plants need 1,100 to 1,200 degree-days to complete their cycle (Medeiros et al 2000). The high temperatures during the experiment (Figure 1) resulted in an accumulation of 1,090 degree-days at 70 DAS (end of the crop cycle), which reduced the common bean cycle and, consequently, negatively affected the yield components, corroborating the results of Costa et al. (2009) and Renato et al. (2013).

The highest water-use efficiency was found with the $f$ factor of 0.32 , which resulted in a grain yield of $0.4 \mathrm{~kg} \mathrm{~m}^{-3}$, being $74.28 \%$ higher, when compared to the highest $f$ factor studied. The wateruse efficiency decreased as the water depths were decreased (Figure 2E). This denotes the common bean crop sensitivity to stressful conditions. Several studies evaluated the water-use efficiency for the common bean crop (Peres et al. 2010, Cunha et al. 2013, Brito et al. 2016), showing results between $0.50 \mathrm{~kg} \mathrm{~m}^{-3}$ and $1 \mathrm{~kg} \mathrm{~m}^{-3}$. This amplitude is due to different crop managements and environmental conditions.
The BRS Estilo cultivar had a higher number of pods per plant (approximately $19.85 \%$ ) and number of grains per pod (18.56\%) than the BRS Pérola (Table 4). These results are attributed to the genetic characteristics of the cultivars, since they were subjected to the same experimental conditions. BRS Pérola has a higher vegetative vigor and higher leaf area index. However, this larger leaf area did not result in a higher production. This is probably due to the lower net photosynthesis because of leaf self-shading, when compared to the BRS Estilo (Silva et al. 2012), which was intensified by the adopted planting system. According to Loomis \& Connor (2002), the interception of solar radiation by the plant canopy (self-shading) is dependent on the leaf area index. In addition, considering the higher percentages found for the yield components of plants of the BRS Estilo cultivar, they probably had a greater adaptability to the soil water deficit conditions due to their greater accumulation of photoassimilates in the stem that were translocated to the pods and grains, and because of the probable increasing and deepening of their root system, which allow them to explore deeper soil layers, to access water and continue their metabolic functions.

BRS Pérola had a mean 100-grain weight of $24.55 \mathrm{~g}$ and BRS Estilo of $21.74 \mathrm{~g}$ (Table 4). These results are below those found in the literature and reported by the holders of these cultivars (greater than 26 g). Guimarães et al. (2017) evaluated the BRS Estilo cultivar and found $19.2 \mathrm{~g}$ for 100-grain weight. Carvalho \& Wanderley (2007) evaluated the BRS Pérola cultivar in rainfed and irrigated systems and found $25.5 \mathrm{~g}$. These are similar results to those found in the present study. Although BRS Pérola had a higher 100-grain weight, its grain yield was $15 \%$ lower than that of the BRS Estilo. This is because the BRS Estilo presents a higher number of pods per plant and number of grains per pod, which are

Table 4. Number of pods per plant (NPP), number of grains per pod (NGP), 100-grain weight (100GW, g), grain yield $\left(\mathrm{GY}, \mathrm{kg} \mathrm{ha}^{-1}\right)$ and water-use efficiency (WUE, $\mathrm{kg} \mathrm{m}^{-3}$ ) of common bean plants for the BRS Pérola and BRS Estilo cultivars submitted to soil water availability factors.

\begin{tabular}{lccccc}
\hline \multicolumn{1}{c}{ Cultivar } & NPP & NGP & $100 \mathrm{GW}$ & GY & WUE \\
\hline BRS Pérola & $4.08 \mathrm{~b}^{1}$ & $3.34 \mathrm{~b}$ & $24.55 \mathrm{a}$ & $757.56 \mathrm{~b}$ & $0.27 \mathrm{~b}$ \\
BRS Estilo & $4.89 \mathrm{a}$ & $3.96 \mathrm{a}$ & $21.74 \mathrm{~b}$ & $883.01 \mathrm{a}$ & $0.32 \mathrm{a}$ \\
\hline
\end{tabular}


yield components responsible for the grain yield of the crop. Melo et al. (2011) also found a higher grain yield for BRS Estilo, with a grain yield $7 \%$ higher, when compared to BRS Pérola. The higher grain yield for BRS Estilo is explained by the common bean compensatory capacity, since this cultivar has a smaller plant size than the BRS Pérola, which is compensated by its yield components (Arf et al. 2011).

The cultivars had a significantly different water-use efficiency (Table 4). BRS Estilo had a water-use efficiency $15 \%$ higher than BRS Pérola with the same water depths.

\section{CONCLUSION}

The use of soil water availability factors $(f$ factor) between 0.30 and 0.35 is recommended for common bean crop grown under similar climate and soil conditions as those in the present study. These $f$ factors result in the maximum agronomic yield and soil water-use efficiency. The BRS Estilo cultivar has a higher water-use efficiency (16\% higher) than the BRS Pérola.

\section{ACKNOWLEDGMENTS}

The authors thank the Fundação de Amparo à Pesquisa do Estado de Minas Gerais (Fapemig), Coordenação de Aperfeiçoamento de Pessoal de Nível Superior (Capes) and Conselho Nacional de Desenvolvimento Científico e Tecnológico (CNPq) for the financial support and granted scholarships.

\section{REFERENCES}

ALLEN, R. G.; PEREIRA, L. S.; RAES, D.; SMITH, M. Evapotranspiración del cultivo. Rome: FAO, 2006.

ALVARES, C. A.; STAPE, J. L.; SENTELHAS, P. C.; GONÇALVES, J. L. de M.; SPAROVEK, G. Köppen's climate classification map for Brazil. Meteorologische Zeitschrift, v. 22, n. 6, p. 711-728, 2013.

AMBACHEW, D.; MEKBIB, F.; ASFAW, A.; BEEBE, S. E.; BLAIR, M. W. Trait associations in common bean genotypes grown under drought stress and field infestation by BSM bean fly. The Crop Journal, v. 3, n. 4, p. 305-316, 2015.

ANDRADE, E. R.; RIBEIRO, V. N.; AZEVEDO, C. V.; CHIORATO, A. F.; WILLIAMS, T. C.; CARBONELL, S. A. Biochemical indicators of drought tolerance in the common bean (Phaseolus vulgaris L.). Euphytica, v. 210, n. 2, p. 277-289, 2016.

ARF, M. V.; BUZETTI, S.; ARF, O.; KAPPES, C.; FERREIRA, J. P.; GITTI, D. de C.; YAMAMOTO, C. J. T. Fontes e épocas de aplicação de nitrogênio em feijoeiro de inverno sob sistema plantio direto. Pesquisa Agropecuária Tropical, v. 41, n. 3, p. 430-438, 2011.

ASFAW, A.; BLAIR, M. W. Quantification of drought tolerance in Ethiopian common bean varieties. Agricultural Sciences, v. 5, n. 2, p. 124-139, 2014.

BERNARDO, S.; MANTOVANI, E. C.; SILVA, D. D.; SOARES, A. A. Manual de irrigação. 9. ed. Viçosa: Ed. UFV, 2019.

BRASIL. Ministério da Agricultura, Pecuária e Abastecimento. Conhecendo a fenologia do feijoeiro e seus aspectos fitotécnicos. 2018. Disponível em: https:// www.infoteca.cnptia.embrapa.br/infoteca/bitstream/ doc/1085830/1/CNPAF2018lvfeijoeiro.pdf. Acesso em: 20 jun. 2018.

BRITO, J. E. D.; ALMEIDA, A. C. S.; LYRA, G. B.; FERREIRA JUNIOR, R. A.; TEODORO, I.; SOUZA, J. L. Produtividade e eficiência de uso da água em cultivo de feijão sob diferentes coberturas do solo submetido à restrição hídrica. Revista Brasileira de Agricultura Irrigada, v. 10, n. 2, p. 565-575, 2016.

CARVALHO, I. R.; KORCELSKI, C.; PELISSARI, G.; HANUS, A.; ROSA, G. Demanda hídrica das culturas de interesse agronômico. Enciclopédia Biosfera, v. 9, n. 17, p. 969-985, 2013.

CARVALHO, W. P.; WANDERLEY, A. L. Avaliação de cultivares de feijão comum para o plantio em sistema orgânico no Cerrado, ciclo 2004/2005. Bioscience Journal, v. 23, n. 3, p. 50-59, 2007.

CASTRO-GUERRERO, N. A.; ISIDRA-ARELLANO, M. C.; MENDOZA-COZATL, D. G.; VALDÉS-LÓPEZ, O. Common bean: a legume model on the rise for unraveling responses and adaptations to iron, zinc, and phosphate deficiencies. Frontiers in Plant Science, v. 7, n. 1, p. 1-7, 2016.

COSTA, L. C.; JUSTINO, F.; OLIVEIRA, L. J. C.; SEDIYAMA, G. C.; FERREIRA, W. P. M.; LEMOS, C. F. Potential forcing of $\mathrm{CO}_{2}$, technology and climate changes in maize (Zea mays) and bean (Phaseolus vulgaris) yield in southeast Brazil. Environmental Research Letters, v. 4, n. 1, p. 1-10, 2009.

CUELLAR-ORTIZ, S. M.; DE LA PAZ ARRIETAMONTIEL, M. P.; ACOSTA-GALlEGOS, J.; COVARRUBIAS, A. A. Relationship between carbohydrate partitioning and drought resistance in common bean. Plant, Cell \& Environment, v. 31, n. 10, p. 1399-1409, 2008. 
CUNHA, P. C. R.; SILVEIRA, P. M.; NASCIMENTO, J. L.; ALVES JÚNIOR, J. Manejo da irrigação no feijoeiro cultivado em plantio direto. Revista Brasileira de Engenharia Agrícola e Ambiental, v. 17, n. 7, p. 735742, 2013.

DARKWA, K.; AMBACHEW, D.; MOHAMMED, H.; ASFAW, A.; BLAIR, M. W. Evaluation of common bean (Phaseolus vulgaris L.) genotypes for drought stress adaptation in Ethiopia. The Crop Journal, v. 4, n. 5, p. 367-376, 2016.

DIPP, C. C. J. A.; WOYANN, L. G.; BOSSE, M. A.; ROMAN, M. H.; GOBATTO, D. R.; FINATTO, T. Drought stress tolerance in common bean: what about highly cultivated Brazilian genotypes? Euphytica, v. 213, n. 5, p. 1-16, 2017.

EMPRESA BRASILEIRA DE PESQUISA AGROPECUÁRIA (Embrapa). Centro Nacional de Pesquisa de Solos. Sistema brasileiro de classificação de solos. Brasília, DF: Embrapa, 2013.

ENDRES, L.; SOUZA, J. L. D.; TEODORO, I.; MARROQUIM, P. M.; SANTOS, C. M. D.; BRITO, J. E. Gas exchange alteration caused by water deficit during the bean reproductive stage. Revista Brasileira de Engenharia Agrícola e Ambiental, v. 14, n. 1, p. 11-16, 2010.

FERREIRA, D. F. Sisvar: a guide for its bootstrap procedures in multiple comparisons. Ciência e Agrotecnologia, v. 38, n. 2, p. 109-112, 2014.

GUIMARÃES, R. A. M.; BRAZ, A. J. B. P.; SIMON, G. A.; FERREIRA, C. J. B.; BRAZ, G. B. P.; SILVEIRA, P. M. Resposta de cultivares de feijoeiro a adubação nitrogenada em diferentes estádios fenológicos. Global Science and Technology, v. 10, n. 1, p. 136-148, 2017.

HOFFMANN, L.; RIBEIRO, N. D.; ROSA, S. S. da; JOST, E.; POERSCH, N. L.; MEDEIROS, S. L. P. Resposta de cultivares de feijão à alta temperatura do ar no período reprodutivo. Ciência Rural, v. 37, n. 6, p. 1543-1548, 2007.

LANNA, A. C.; MITSUZONO, S. T.; TERRA, T. G. R.; VIANELLO, R. P.; CARVALHO, M. A. D. F. Physiological characterization of common bean (Phaseolus vulgaris L.) genotypes, water-stress induced with contrasting response towards drought. Australian Journal of Crop Science, v. 10, n. 1, p. 1-6, 2016.

LEMOS, L. B.; OLIVEIRA, R. S. de; PALOMINO, E. C.; SILVA, T. R. B. da. Características agronômicas e tecnológicas de genótipos de feijão do grupo comercial Carioca. Pesquisa Agropecuária Brasileira, v. 39, n. 4, p. 319-326, 2004.

LOOMIS, R. S.; CONNOR, D. J. Ecología de cultivos: productividad y manejo en sistemas agrarios. Madrid: Mundi-Prensa, 2002.
MANFRON, P. A.; LAZZAROTTO, C.; MEDEIROS, S. L. P. Trigo: aspectos agrometeorológicos. Revista do Centro de Ciências Rurais, v. 23, n. 2, p. 237-239, 1993.

MANTOVANI, E. C.; SALASSIER, B.; PALARETTI, L. F. Irrigação: princípios e métodos. 3. ed. Viçosa: Ed. UFV, 2009.

MAROUELLI, W. A.; OLIVEIRA, A. S.; COELHO, E. F.; NOGUEIRA, L. C.; SOUSA, V. F. Irrigação e fertirrigação. In: SOUSA, V. F. de; MAROUELLI, W. A.; COELHO, E. F.; PINTO, J. M.; COELHO FILHO, M. A. (ed.). Irrigação e fertirrigação em fruteiras e hortaliças. Brasília, DF: Embrapa Informação Tecnológica, 2011. p. 159-232.

MEDEIROS, G. D.; ARRUDA, F. B.; SAKAI, E.; FUJIWARA, M.; BONI, N. R. Crescimento vegetativo e coeficiente de cultura do feijoeiro relacionados a graus dia acumulados. Pesquisa Agropecuária Brasileira, v. 35, n. 9 , p. $1733-1742,2000$.

MEDRANO, H.; TOMÁS, M.; MARTORELL, S.; FLEXAS, J.; HERNÁNDEZ, E.; ROSSELLÓ, J.; POU, A.; ESCALONA, J. M.; BOTA, J. From leaf to wholeplant water-use efficiency (WUE) in complex canopies: limitations of leaf WUE as a selection target. The Crop Journal, v. 3, n. 3, p. 220-228, 2015.

MELO, L.; DEL PELOSO, M. J.; PEREIRA, H.; FARIA, L. C. de; COSTA, J. G. C. da; CABRERA DIAZ, J. L.; VIEIRA JUNIOR, J. R. BRS Estilo: cultivar de feijão carioca com grãos claros, arquitetura ereta e alto potencial produtivo. In: CONGRESSO NACIONAL DE PESQUISA DE FEIJÃO, 2011, Goiânia. Anais... Santo Antônio de Goiás: Embrapa Arroz e Feijão, 2011. 1 CD-ROM.

NEPOMUCENO, A. L.; NEUMAIER, N.; FARIAS, J. R. B.; OYA, T. Tolerância à seca em plantas: mecanismos fisiológicos e moleculares. Biotecnologia Ciência \& Desenvolvimento, v. 23, n. 1, p. 12-18, 2001.

OLSOVSKA, K.; KOVAR, M.; BRESTIC, M.; ZIVCAK, M.; SLAMKA, P.; SHAO, H. B. Genotypically identifying wheat mesophyll conductance regulation under progressive drought stress. Frontiers in Plant Science, v. 7, n. 1, p. 1-14, 2016.

OSAKABE, Y.; OSAKABE, K.; SHINOZAKI, K.; TRAN, L. S. P. Response of plants to water stress. Frontiers in Plant Science, v. 5, n. 1, p. 1-8, 2014.

PERES, J. G.; BRUGNARO, C.; SOUZA, C. F.; PAPINI, D. H.; CRUGER, F. F.; ROVEA, R. J. P. Avaliação da produtividade de grãos e do consumo de água de seis cultivares de feijoeiro para plantio de inverno na região de Araras - SP. Irriga, v. 15, n. 3, p. 335-343, 2010.

RENATO, N. S.; SILVA, J. B. L.; SEDIYAMA, G. C.; PEREIRA, E. G. Influência dos métodos para cálculo 
de graus-dia em condições de aumento de temperatura para as culturas de milho e feijão. Revista Brasileira de Meteorologia, v. 28, n. 4, p. 382-388, 2013.

RIBEIRO, N. D.; DOMINGUES, L. S.; ZEMOLIN, A. E. M. Avaliação dos componentes da produtividade de grãos em feijão de grãos especiais. Cientifica, v. 42, n. 2 , p. 178-186, 2014.

SILVA, R. R.; SCARIOTTO, S.; MALAGI, G.; MARCHESE, J. A. Análise de crescimento em feijoeiro cultivado sob diferentes densidades de semeadura. Scientia Agraria, v. 13, n. 2, p. 41-51, 2012.

VALE, N. M.; BARILI, L. D.; ROZZETO, D. S.; COIMBRA, J. L. M.; GUIDOLIN, A. F.; KÖOP, M. M. Avaliação para tolerância ao estresse hídrico em feijão. Biotemas, v. 25, n. 3, p. 135-144, 2012.
VIEIRA, C.; PAULA JÚNIOR, T. J.; BORÉM, A. Feijão. 2. ed. Viçosa: Ed. UFV, 2006c.

VIEIRA, G. H. S.; MANTOVANI, E. C.; SEDIYAMA, G. C.; MONACO, P. A. V. Lâminas de irrigação em canade-açúcar para diferentes condições de disponibilidade hídrica. Irriga, v. 1, n. 2, p. 137-148, 2015a.

VIEIRA, R. F.; LIMA, M. S.; NEVES, J. C. L.; ANDRADE, M. J. B. Adubação. In: CARNEIRO, J. E.; PAULA JÚNIOR, T. J.; BORÉM, A. (ed.). Feijão: do plantio à colheita. Viçosa: Ed. UFV, 2015b. p. 145-172.

VILLA NOVA, N. A.; PEDRO JUNIOR, M. J.; PEREIRA, A. R.; OMETTO, J. C. Estimativa de graus-dia acumulados acima de qualquer temperatura-base em função das temperaturas máxima e mínima. Ciência da Terra, v. 30, n. 1, p. $1-8,1972$. 